\title{
Toward Greater Implementation of Motivating Factors for a Better Quality of School: Case in Kosovo
}

\author{
Doc. Eliza Avdiu
}

\author{
Faculty of Education, \\ University of Prishtina, Prishtine, Kosove \\ eliza.avdiu@hotmail.com
}

Faton Avdiu

Faculty of Management -Informatics and Economics, University of Prishtina, Prishtine, Kosove favdiu@gmail.com

\section{Doi:10.5901/jesr.2013.v3n7p545}

\begin{abstract}
Changes in recent years in the field of education show that our country seems to be reformed based on European standards, making it comparable to other countries education system. However the experience in practice shows the gaps which limit creation of an environment that promotes and motivates human society best values. This paper is focused on factors which facilitate/obstruct development of quality in the field of education by offering examples which allow solution.In this case, the paper presents factors that contribute to more successful and safer school development, starting from the reasons which obstruct/facilitate success, such as improper application of teaching methods, teacher and parent accountability towards students, punitive and preventive measures for different occurrences such as school drop-outs, low social-economic levels, closer cooperation between MEST and schools, faster and wider application of the ICT, etc. The essence of the request for greater integration of all these factors toward student motivation in aiding school work is a need for conditions which currently should be entwined in our schools in the service of placing better quality, systematic, selected and functional education in our schools by creating the circumstances for the students to have an internal push to work on activities and tasks which enrich their spiritual and intellectual knowledge.
\end{abstract}

Keywords: factors obstructing/facilitating success, student motivation, quality education,

\section{Introduction}

School serves as a necessity to transmit knowledge, experience, customs, features, and civilizations from one generation to another and by a full change in our country education has stepped onto the path of overall democratization, yet at the same time bearing many disturbing problems. Education, being the brain of every society, is tasked in preparing the individual for a life with a better future, giving them the necessary abilities to adapt to an ever changing society and also contribute to its development. ${ }^{1}$

Like all other countries in the world, our country also faces the challenges in enhancing the education system in general, starting from the need to include various motivational factors towards standardization of the general education processes. $^{2}$

The importance of raising this issue is essential in order to identify the problems in the future and evaluate necessary factors and to implement in practice the need to increase the quality of teaching and learning.

Also, the purpose of this paper is to inform on how did the implementation of reforms affect education whereby different problems emerged in teaching and learning and in general created barriers in the overall educational process.

\footnotetext{
1 http://www.izha.edu.al/files/standartet/Standardet_TIK_BR.pdf

${ }^{2}$ Kryeziu,A. (2010),,Qeverisja dhe udheheqja ne arsim”, ,,Shkolla dhe komuniteti”, mars 10 , KEC-Prishtine
} 


\section{Facing the Need for Change}

Trying to improve the conditions in education teachers faced great obstacles in using new teaching and learning methodologies and students in dealing with these methods. There are teachers who are against these reforms because they are unable to change and this is one of the reasons reform was misunderstood. A large number of teachers are not implementing these new techniques in practice. Non-implementation of new methodologies calls for an urgent need to organize and prepare permanent monitoring for all school structures, by the competent people, in order to support and advance the work in schools. Developing a modern education system depends upon teacher's continuous professional training.

Our institutions and the society in general must support this process by creating systems and programs that address the teachers need for various trainings related to increase the quality of education. Education development institutions should also prepare curricula for all institutions dealing with professional specialization of teachers and educators. ${ }^{3}$

Parents warning system, used to immediately inform the parents if their child is absent from school, is still not present in many schools. Telephone communication or parents visiting the school are still the only methods by which the parents can receive information on the state of their child.

Schools also are not offering any extra curriculum activities to children, therefore students themselves organize entertainment in their free time, which is usually not constructive. Most of students say they do not feel comfortable talking to their parents about various problems, and about many problems which could manifest later as is the case of lack of security in schools. ${ }^{4}$

Another factor which is a point of concern for the students is drugs use. Approximately $20 \%$ of high school students use different types of drugs, the average age for first time drug consumption has dropped and now it affects even the age of $12-13$, respectively grade VIII in elementary schools. Cannabis is sold in most of the bars around elementary and high schools in Kosovo and teachers are not well trained on drugs, therefore they cannot respond to this in the best possible manner. Although there is a National Strategy against Narcotics in the Republic of Kosovo this Strategy is not being implemented due to the lack of cooperation and coordination between different sectors in the Government of Kosovo. ${ }^{5}$

\section{Strengthening cooperation school-community}

Also, school cooperation with parents equally affects the family to change, have new opinion about the school and take part in joint responsibility.

In Kosovo there can never be successful changes if there is no improvement in creating a very professional partnership or cooperation between the school and society at large.

School cooperation with the community brings many benefits to education: school efficiency increases, teaching quality increases, functional governance, great results in learning, training people for work and professions, economic and living standard increase... Human values and life skills are encouraged, especially lifelong learning.

Partnership can be achieved through the following forms:

- Teacher and school principals training

- Help for schools

- Support in strategic planning

- Creation of dominant vision and orientation towards teaching and learning

- Pursuing advances in school efficiency and quality of work in schools

- Establishing learning professional cooperation networks

There are so many forms of advanced school - institutions partnership in higher education, aiming to verify problems and work on correcting them. ${ }^{6}$

Naturally, an unsafe and negative environment damages children's readiness and motivation to learn, which

\footnotetext{
${ }^{3}$ Gajraku,G. \& Mexhuni,A. hulumtim „Ndikimet e trajnimeve ne procesin mesimore”(2008), Prishtine

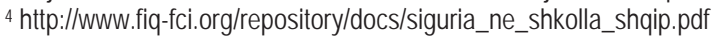

${ }^{5} \mathrm{http}: / /$ www.assembly-kosova.org/?cid=1,128,5618

6 http://sq.wikibooks.org/wiki/Shkolla_dhe_komuniteti_dy_sisteme_t\%C3\%AB_nd\%C3\%ABrvarura/2
} 
consequently brings bad results in teaching, conflicts and misunderstandings with parents and as well as with teachers. This phenomenon further demotivates students and increases the tendency to make dropping school a possible solution.

Dropping out of teaching process is becoming a serious issue in our society and we should know the factors driving the youth towards this choice, the family should be the first safety, sometimes by the lack of establishing effective relationships and the second safety are the teachers, with whom they are in contact outside the family process; having in mind the importance and necessity of these two institutions, family and school, and concrete responsibilities of both parties in school dropout.

Not knowing the facts obstructs success:

- Lack of motivation and seriousness

- Non-preparation and the fear of low marking

- Overburdened curricula

- Lack of communication and positive relationships

- Students' lack of patience

- Lack of clear rules sensitive towards the students needs

- Lack of accountability and interest by class supervisors

- Overcrowding classes makes student testing very rare. ${ }^{7}$

\section{Comprehensive integration of Technological Achievements into Schools}

In a world which is constantly orienting itself toward technology and globalization, understanding, use and establishing Information Technology and Communication (ITC) culture has become a very important factor which enables a more modern student education, capable of facing the challenges of development. In teaching the necessary technological skills to students new teaching methods should be used compared to methods used in traditional teaching. Students, using these new technological tools gain computer skills, the skills which they will be able to use in the future at their working places.

Main benefit coming from the efficient use of new technologies is the increase of student ability to focus on learning, which improves understanding and transfers the content to long-term memory. Based on this justification the aim is to transform traditional classes into classes conceptualized on the basis of technology. ${ }^{8}$

Wide incorporation of technological systems into learning process aims to make the students confident and productive technology users at the end of their study cycles, and prepared to be capable competitors at the European labor market. Pursuant to this, it is also required that the teachers also possess basic ITC (Information Technology and Communication) skills and contribute to the increase of quality of teaching by integrating and wide usage of ITC in teaching processes. ${ }^{9}$

School evolution requires well prepared staff, but the students should also be in line with the newest trends of time. It is exactly the use of computers and information technology in classes which stimulates student imagination and makes the student creative and investigative for continuous learning. It is necessary to teach the students the skills of $21^{\text {st }}$ century, in which we live, and this can be done only if their teachers are functioning towards achieving their mission in the best possible manner. ${ }^{10}$

\section{What is the opinion on what the school offers currently and what changes should be made for empowering schools?}

\subsection{Discussions and parents and teachers requests}

Analyzing discussions and opinions of some parents of children attending school in low secondary schools in Prishtina we are trying to answer these questions which continue to preoccupy our society.

Some categories of different education staff acknowledge that current teaching conditions are insufficient to bring

\footnotetext{
${ }^{7}$ Pode,R.(2012), ,,Braktisja e shkolles, fenomen qe kercenon arsimin shqipetar”, may 7,

${ }^{8} \mathrm{http}$ ://infoalbania.org/lajme-home/lajme-intervista/32702-dixitalizimi-i-shkollave-nis-projekti-ne-gjithe-vendin.html

$9 \mathrm{http}: / /$ planipolis.iiep.unesco.org/upload/Albania/Albania-Strategy-Pre-university-2009-2013-alb.pdf

${ }^{10}$ Kryeziu,F.(2013), ,Rendesia e perdorimit te teknologjise dhe informacionit ne mesimdhenien e gjuhes angleze", february 01,2013
} 
sustainable improvement in teaching system performance and student achievements. They express their concern by addressing insufficient commitment, initially to highest instances (MEST), on restraints characterizing modern teaching methods and their efficient implementation in the teaching process due to the fact that teachers are not prepared accordingly and this requires great commitments.

One of the important conclusions emerging is that regardless of the teachers commitment to organize modern teaching in the learning process, there cannot be increase in teaching process performance as long as the number of students remains to be very high (even over 40 students).

Moreover, in general teachers' opinion, in many cases they stress that students are under very low parent care although they are important factors in the forming of them, therefore closer cooperation of parents and students and teachers shall bring positive effects.

The nature of the work changed and continues to change by combining an all-inclusive approach for the students to take on the role of knowledge and information receivers and hence it is more than necessary to include interactive approach which enables broad selection of knowledge sources in order to prepare students for full and productive life. Despite the fact that the largest number of students has the knowledge about technological equipment, however it is the school itself doesn't offer this.

All main and many other strategies highlight the need for urgent intervention by the high national institutions, expecting them to play a progressive role in achieving the objectives and by bringing a new climate for the purpose of increasing the standards in educational structures.

\section{Conclusions}

- In order to respond to ongoing changes and challenges I believe that the phenomena outlined above and many others, which are the main links in the chain of subjects which consequently brought to debates, should be supported by experience gained throughout the years and incite fruitful integration into the European network of educational structure.

- Several qualitative researches compare our schooling with many other democratic countries and here I believe that education, as a discipline for evolving mind and character, should work as an institution for wider formation, in regard to respecting opinions, ideas and methods, by accepting every change and problem and linking what is learned with their experiences, raising questions over the truthfulness and by building other examples which are a need and necessity of this time and the profession we exercise.

- Today, to function in the time and environment with ever growing demands for sustainable development is necessary to transform the educational process in all its segments.

- The fact that education is in the middle of efforts to support it towards the modern challenges for creating a new climate and make it comparable to educational structures in developed countries, the biggest responsibility falls over local state institutions in accelerating this process by identifying problems in planning and facing the changes which touch upon today's educational process.

- In order to identify factors which are obstructing the effective development of the educational process the entire work and attention should be addressed on the basis of respecting the law by supporting, stimulating specialized organisms to actively partake by undergoing a series of quick and qualitative changes.

- In this view school institution is preconditioned by the qualitative modern technology and information preparedness in the fields of educational system and cannot remain indifferent to rapid technological progress which exercises direct influence over the society.

\section{Acknowledgement}

Personal experience, original literature and different websites, as well as student, parents and teacher impressions, were used for making this paper.

\section{References}

http://www.izha.edu.al/files/standartet/Standardet_TIK_BR.pdf

Kryeziu,A. (2010),,Qeverisja dhe udheheqja ne arsim”, „,Shkolla dhe komuniteti”,mars 10 , KEC-Prishtine http://sq.wikibooks.org/wiki IShkolla_dhe_komuniteti_dy_sisteme_t\%C3\%AB_nd\%C3\%ABrvarura/2 
Gajraku,G. \& Mexhuni,A. hulumtim „Ndikimet e trajnimeve ne procesin mesimore”(2008), Prishtine http://www.mashtgov.net/advCms/documents/Raport\%20i\%20hulumtimit.pdf http://www.fiq-fci.org/repository/docs/siguria_ne_shkolla_shqip.pdf http://www.assembly-kosova.org/?cid=1,128,5618

http://sq.wikibooks.org/wiki/Shkolla_dhe_komuniteti_dy_sisteme_t\%C3\%AB_nd\%C3\%ABrvarura/2

Pode,R.(2012), , Braktisja e shkolles, fenomen qe kercenon arsimin shqipetar”, may 7 ,

http://www.dituria.se/index.php?option=com_content\&view=article\&id=693:rezarta-pode-braktisja-e-shkolles-fenomen-qe-kercenonarsimin-shqiptar\&catid $=44:$ debattartiklar\&ltemid $=63$

http://infoalbania.org/lajme-home/lajme-intervista/32702-dixitalizimi-i-shkollave-nis-projekti-ne-gjithe-vendin.html http://planipolis.iiep.unesco.org/upload/Albania/Albania-Strategy-Pre-university-2009-2013-alb.pdf

Kryeziu,F.(2013), ,,Rendesia e perdorimit te teknologjise dhe informacionit ne mesimdhenien e gjuhes angleze”, february 01 , http://www.dituria.se/index.php?option=com_content\&view=article\&id=989:f 